\title{
miR-138 exerts anti-glioma efficacy by targeting immune checkpoints
}

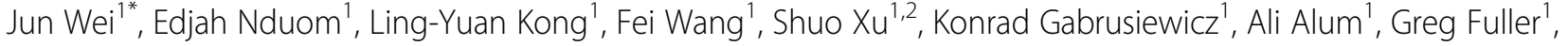 \\ George Calin ${ }^{1}$, Amy B Heimberger ${ }^{1}$ \\ From Society for Immunotherapy of Cancer 28th Annual Meeting \\ National Harbor, MD, USA. 8-10 November 2013
}

The immune checkpoints, CTLA-4 and PD-1, are negative regulators of $\mathrm{T}$ cell activation and are inducers of FoxP3+ Tregs. Monoclonal antibody therapy to each has demonstrated tumor regression in clinical trials and potent therapeutic synergy has been observed when used in combination. MicroRNAs (miRs) have been shown to modulate gene transcripts involved in tumorigenesis and can target tumor-mediated immune suppression. On the basis of differential miRNA gene expression libraries from glioblastoma patients, miR-138 was identified as a top down regulated candidate. On glioma tumor microarrays, miR-138 expression is heterogeneous among the various grades and pathologies. Target binding algorithms predicted that miR-138 could bind CTLA-4 and PD-1. Transfection of human CD4+ T cells with miR-138 suppressed CTLA-4-, PD-1-, and FoxP3- expression in vitro. Treatment of established subcutaneous GL261 murine glioma cells in immune competent C57BL/6 mice with miR-138 or scramble control administered intravenously demonstrated that gliomas started to shrink as soon as miR-138 was administered. Moreover, the gliomas continued to regress even after miR-138 treatment was discontinued. In contrast, tumors kept growing aggressively in scramble miRNA-treated and untreated tumor-bearing mice groups. Furthermore, in C57BL/6 mice with established intracerebral GL261 treated with i.v. administered miR-138, median survival was 33.5 days relative to mice treated with scramble control with a median survival of 23.5 days $(\mathrm{P}=0.011)$. Intravenous treatment of mice with established intracerebral gliomas with miR-138 relative to the scramble control reduced the relative incidence of Tregs by $51 \%$ $(\mathrm{P}=0.03)$ within the glioma microenvironment. Formulation equivalency studies in vivo indicate that DOTAP

${ }^{1}$ University of Texas MD Andrson Cancer Center, Houston, TX, USA Full list of author information is available at the end of the article causes rapid translocation of miRNAs into the peripheral blood compartment indicating that miR-138 may have rapid translational potential as a novel immunotherapeutic agent for neoplasms.

\section{Authors' details}

'University of Texas MD Andrson Cancer Center, Houston, TX, USA. ${ }^{2}$ Qilu Hospital of Shandong University, Jinan, China.

Published: 7 November 2013

doi:10.1186/2051-1426-1-S1-P177

Cite this article as: Wei et al:: miR-138 exerts anti-glioma efficacy by targeting immune checkpoints. Journal for ImmunoTherapy of Cancer 2013 1(Suppl 1):P177.
Submit your next manuscript to BioMed Central and take full advantage of:

- Convenient online submission

- Thorough peer review

- No space constraints or color figure charges

- Immediate publication on acceptance

- Inclusion in PubMed, CAS, Scopus and Google Scholar

- Research which is freely available for redistribution

Submit your manuscript at www.biomedcentral.com/submit
C Biomed Central
C Biomed Central

( 2013 Wei et al; licensee BioMed Central Ltd. This is an Open Access article distributed under the terms of the Creative Commons Attribution License (http://creativecommons.org/licenses/by/2.0), which permits unrestricted use, distribution, and reproduction in any medium, provided the original work is properly cited. 